Agro-Science Journal of Tropical Agriculture, Food, Environment and Extension Volume 20 Number 1 (January 2021) pp. $80-86$

ISSN 1119-7455

\title{
MOLECULAR IDENTIFICATION OF FUNGI ASSOCIATED WITH AVOCADO (Persea americana MILL.) FRUITS
}

\author{
${ }^{* 1}$ Iyanyi N.G., ${ }^{1,2}$ Ataga A.E., ${ }^{2}$ Rotimi I.S. and ${ }^{1}$ Blessing I. \\ ${ }^{1}$ Department of Plant Science \& Biotechnology, \\ University of Port Harcourt, Port Harcourt, Nigeria \\ ${ }^{2}$ Regional Center for Biotechnology \& Bioresources Research, \\ University of Port Harcourt, Port Harcourt, Nigeria \\ *Corresponding author's email: nkechi.iyanyi@gmail.com
}

\begin{abstract}
Avocado (Persea americana Mill.) is grown for its nutritious fruit. However, the quantity and quality of these fruits are threatened by some fungal organisms which can cause health complications when it is consumed by man. DNA extraction provides a unique tool for identification of organisms. This study was conducted to isolate and identify fungal species associated with avocado fruit using both morphological and molecular techniques. Fungal species were isolated from Persea americana purchased from Choba market, Port Harcourt, Rivers State, Nigeria using Potato Dextrose Agar (PDA) as a growth medium. The morphology of isolated fungi on PDA were cotton-like blackish grey spots, white villous colonies, greyish powdery spores and black spores for isolates 1 to 4 respectively. Extraction of DNA from fungal isolates was carried out using Zymo Fungal/Bacteria DNA Miniprep Kit. PCR amplification of the ITS1-2 regions of isolates was carried out using fungal universal primer pair; ITS4 and ITS5.PCR amplification of the ITS1-2 gene sequences yielded amplicons between 537-580 base pairs. PCR products were sequenced and the sequencing result after BLAST search revealed the identity of the four fungal species as follows: Lasiodiplodia theobromae, Fusarium proliferatum, Penicillium sp. and Aspergillus niger. This study will promote the knowledge of specific fungal species associated with Persea americanna and help plant pathologists to proffer preventive and control measures to enhance fruit protection and yield quality.
\end{abstract}

Key words: fungi, isolation, Persea americana, phylogeny, sequencing

\section{INTRODUCTION}

Avocado (Persea americana) originated from Central America and Southern Mexico. Based on archaeological evidence found in Tehuacán, Puebla (Mexico), it is believed to have appeared ca. 12,000 years ago (Yahia and Woolf, 2011). P. Americana fruit is by itself a complete food containing nine essential amino acids in an unbalanced proportion (Bergh, 2012). Avocado, like many tree crops, is propagated clonally through grafting to preserve commercially desirable varieties. The consumption of avocado fruits has tremendously increased globally and avocado is now an important fruit traded in the international market (Radha and Mathew, 2007).

Persea Americana fruits are purple to green in colour with smooth or warty skin depending on variety. The flesh of the fruit is yellowish-green in colour and has the consistency of butter. Each fruit contains one large seed. P. americana trees grown from seed can take 4-6 years to start fruiting, whereas grafted plants fruit within 1-2 years. The leaves are elongated and could be elliptic, lanceolate, oval, obovate or ovate in shape (Schaffer et al., 2013).
Avocado is mostly cultivated because of its use as food as the pulp is a rich source of protein, fats, energy and minerals (Belé, 2010). Avocado fruit is one of the sources of Vitamin A consumed by pregnant women (Eze and Okeke, 2012). In addition to food use, the consumption of avocados has been associated with various health benefits, such as reduction in cholesterol and decreased risk of cardiovascular disease. The presence of squalene, omega fatty acids, tocopherols and phytosterols in the lipidic fraction confers the fruit its recognized health benefits (Duarte et al., 2016). Avocado contains fat-soluble vitamins more than other fruits; high levels of potassium, protein and unsaturated fatty acids. The pulp contains oil, and is broadly used in the cosmetics and pharmaceutical industry. Fluid obtained from avocado leaves is also used in pharmaceutical industries. It is also a source of glutathione which is a powerful antioxidant against carcinogenic compounds (Wang et al., 2012).

Persea americana is attacked by many diseases, some of which are root rot caused by Phytophthora 
palmivora (Machado et al., 2012), gummosis and root necrosis caused by Phytophthora nicotianae (Machado et al., 2013). Molecular-based technologies are the most reliable tools for characterizing microorganisms due to the fact that they deal with the genetic composition of organisms. Molecular tools have made it possible to obtain indepth information on analyses of systems subject to climate changes (Xue et al., 2016), foodstuffs, agriculture, industrial settings and across the environmental sciences (Long et al., 2016). Highly conserved oligonucleotide primers, such as those used for the amplification of the internal transcribed spacer (ITS) region for fungi has been developed (Schoch et al., 2012; Tedersoo et al., 2015).This study was therefore aimed at isolating and identifying fungal species associated with avocado fruits using morphological and molecular techniques.

\section{MATERIALS AND METHODS}

\section{Study Area and Sample Collection}

The study was conducted at the Regional Centre for Biotechnology \& Bioresources Research Laboratory, University of Port Harcourt. Sequencing of the PCR products was done at the International Institute for Tropical Agriculture (IITA), Ibadan. The $P$. americana fruits used in the study were purchased from vendors in Choba market, Port Harcourt, Rivers State in April, 2019. Choba is between latitude $4.8941^{\circ} \mathrm{N}$ and longitude $6.9263^{\circ} \mathrm{E}$. Fruits were purchased from different vendors and transported to the laboratory in sterile Ziploc bags.

Isolation of Fungi from Persea americana Fruits Fungi were isolated from $P$. americana fruits using serial dilution method. Ten avocado fruits were used in replicates; three replicates for each fruit. One gram (1 g) of infected portion of avocado fruits was mixed with $10 \mathrm{ml}$ of distilled water to form the stock solution. Five-fold serial dilution was made and $0.1 \mathrm{ml}$ aliquot of the $10^{-4}$ dilution was aseptically transferred onto freshly prepared Potato Dextrose Agar (PDA) plates. The plates were incubated at room temperature $\left(25 \pm 2^{\circ} \mathrm{C}\right)$ for 7 days. After incubation the plates were examined for fungal growth. Individual colonies were sub-cultured on PDA to obtain pure cultures. The morphological characteristic of the mycelium of each isolate was noted but this was not used in identification of the organisms. Pure cultures of fungi were stored in refrigerator at $4^{\circ} \mathrm{C}$ prior to DNA extraction.

Fungal DNA Extraction, Gene Amplification and Sequencing

Quick-DNA $^{\mathrm{TM}}$ Fungal Mini Prep Kit (Zymo Research Group, California, and USA) was used to extract Genomic DNA of the isolated fungi. The protocol of the above named kit was used with modifications. A sterilized surgical blade was used to scrap off the fungal mycelium from the culture plate for each fungal isolate and placed in a sterilized mortar. $750 \mu \mathrm{l}$ of bashing bead buffer was added to the sample before homogenizing with liquid nitrogen. The homogenized sample was transferred to an Eppendorf tube and centrifuged as indicated in the protocol. Cell lysis, precipitation and DNA purification were carried out following the manufacturer's protocol. Pure DNA was stored at $4^{\circ} \mathrm{C}$ for further analysis. DNA concentration and purity of each of the fungal isolates was determined using Nanodrop 2000c spectrophotometer (Thermo Fisher Scientific, USA). DNA quality was determined by gel electrophoresis using $1 \%$ agarose gel.

ITS4-forward (5'-CCTCCGCTTATTGATATGS-3') \& ITS5-reverse (5'-GAAGTAAAAGTCGTAACAAGG-3') primer pair were used to amplify fragments of the nuclear ribosomal DNA (rDNA) through Polymerase Chain Reaction (PCR). PCR was carried out in a final volume of $25 \mu$ l containing 2.5 $\mu \mathrm{l}$ of $10 \times$ PCR buffer, $1 \mu \mathrm{l}$ of $25 \mathrm{mM} \mathrm{MgCl}, 1 \mu \mathrm{l}$ each of forward primer and reverse primer, $1 \mu \mathrm{l}$ of DMSO, $2 \mu \mathrm{l}$ of $2.5 \mathrm{mM}$ NTPs, $0.1 \mu \mathrm{l}$ of $5 \mu \mu^{-}$ ${ }^{1}$ Taq DNA polymerase, $3 \mu \mathrm{l}$ of $10 \mathrm{ng} \mu \mathrm{l}^{-1}$ DNA and $13.4 \mu 1$ Nuclease-free water. Amplification was performed in a thermal cycler (Eppendorf) using an initial denaturation step of $94^{\circ} \mathrm{C}$ for $5 \mathrm{~min}$., followed by 36 cycles of denaturation at $94^{\circ} \mathrm{C}$ for $30 \mathrm{~s}$, annealing at $5^{\circ} \mathrm{C} 4$ for $30 \mathrm{~s}$ and elongation at $72^{\circ} \mathrm{C}$ for $45 \mathrm{~s}$. These were followed by a final elongation step at $72^{\circ} \mathrm{C}$ for $7 \mathrm{~min}$. and hold temperature at $10{ }^{\circ} \mathrm{C}$. Amplified fragments were visualized on safe view- stained $1.5 \%$ agarose gel under Ultraviolet (UV) light.

PCR products were sequenced on an ABI 3500 genetic analyzer (Thermo Fisher Scientific, Massachusetts, U.S.A.). Sanger sequencing was done using a DNA primer, single-stranded DNA template, deoxynucleotide triphosphates (dNTPs), a DNA polymerase and di-deoxynucleotide triphosphates (ddNTPs). Each dideoxynucleotide (ddNTP) incorporated at intervals terminated DNA chain elongation as they lack a 3'-OH group which is responsible for the formation of a phosphodiester bond between two nucleotides. This terminated the extension of DNA.

\section{Data Analysis}

Frequency of occurrence of fungal isolates on PDA was calculated using simple mean and percentages. The sequences of the ITS1-2 Genes of the fungal isolates were edited and trimmed to remove sequencing errors on MEGA X. Sequences were blasted on National Centre for Biotechnology Information (NCBI) database for identification of the organisms. The sequences obtained were compared with sequences in GenBank. Alignment of sequences was carried out using Clustal W. Best BLAST hits were used for the construction of neighbor-joining phylogenetic tree using the Maximum composite likelihood method on MEGA X software (Kumar et al., 2018). 


\section{RESULTS}

\section{Fungal Isolates of Persea americana Fruits}

Four fungal isolates were obtained from Persea americana fruits. The frequency of occurrence and morphological description of each isolate is presented in Table 1 . Isolate 1 had the highest frequency (7.8) followed by isolate 4 (5.8). The pure cultures of the isolates are presented in Plate 1.

\section{DNA Concentration, Purity and Quality}

Genomic DNA from the fungal isolates measured revealed the concentration and purity of the fungal species as presented in Table 2. The genomic DNA of the fungal isolates showed clear bands on gel when viewed under UV light as presented in Plate 2 . This shows that the DNA was of good quality.

Table 1: Frequency of occurrence of fungi isolated from Persea americana fruits

\begin{tabular}{clcc}
\hline Fungal & Morphological & \multicolumn{2}{c}{ Frequency of occurrence } \\
\cline { 2 - 4 } isolate & Description & Mean & $\%$ \\
\hline 1 & Cotton like blackish grey spots & 7.8 & 33.9 \\
2 & White villous colony & 4.1 & 17.8 \\
3 & Greyish powdery spores & 5.3 & 23.0 \\
4 & Black spores & 5.8 & 25.2 \\
\hline
\end{tabular}
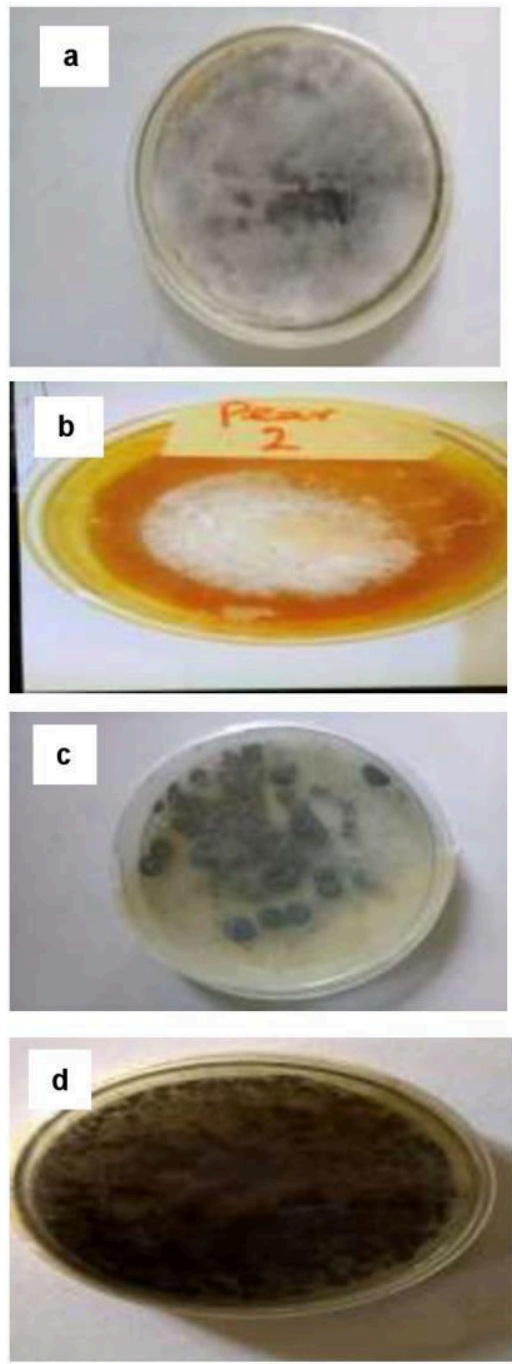

Plate 1: Pure culture of fungi obtained from Persea americana fruits. Alphabets $a$ to $d$ represent the isolates viz Lasiodiplodia theobromae (a); Fusarium proliferatum (b); Penicillium sp. (c); and Aspergillus niger (d)
Table 2: Concentration and purity of DNA extracted from fungal isolates of Persea americana fruits

\begin{tabular}{lcc}
\hline $\begin{array}{l}\text { Fungal } \\
\text { Isolate }\end{array}$ & $\begin{array}{c}\text { Nucleic acid conc. } \\
(\mathrm{ng} / \mu \mathrm{l})\end{array}$ & $\begin{array}{c}\text { Absorbance at } \\
260 / 280 \text { (Purity) }\end{array}$ \\
\hline 1 & 82.8 & 2.0 \\
2 & 16.8 & 2.5 \\
3 & 82.4 & 2.0 \\
4 & 83.1 & 2.0 \\
\hline
\end{tabular}

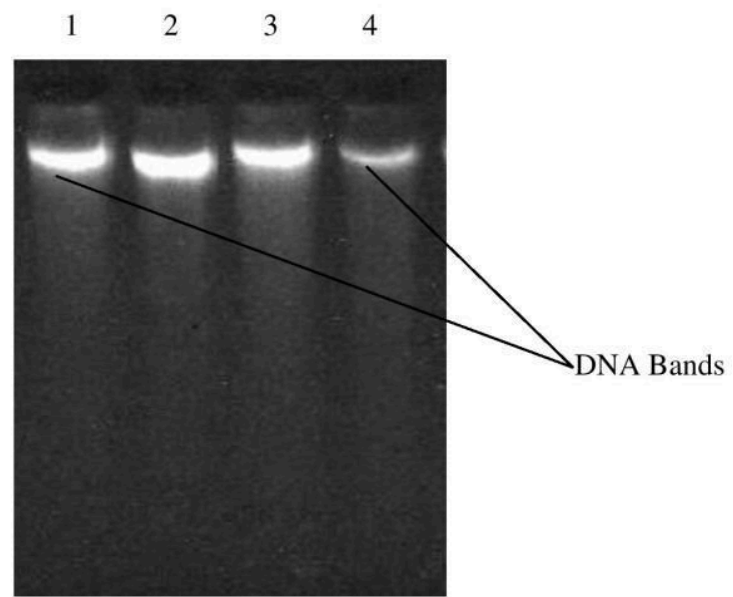

Plate 2: Gel electrophoresis of genomic DNA of fungal isolates (The numbers correspond to the fungal isolate IDs)

\section{PCR Products Obtained from Amplification of ITS Gene}

The result of the amplified ITS1-2 gene sequences of the fungal isolates is presented in Plate 3. The amplified DNA showed bands on gel when observed under UV light.

\section{DNA Sequences and Blast Results}

The ITS 1-2 gene sequences of the fungal isolates were determined to be 537, 553, 584 and 580 base pairs. The alignment scores of the sequences were

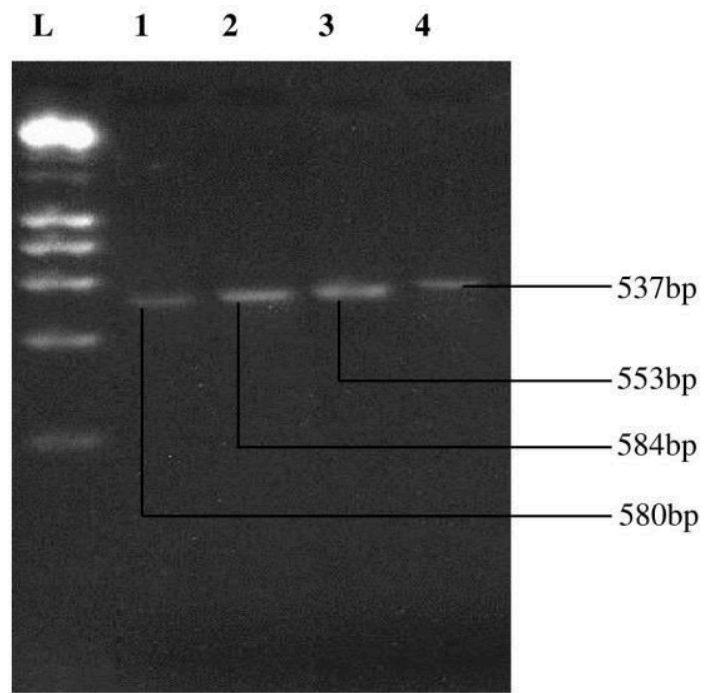

Plate 3: PCR products generated from ITS 1-2 gene sequences of the fungal isolates

$\mathrm{L}$ : $1 \mathrm{~kb}$ DNA ladder; the numbers 1 to 4 represent the fungal isolates 
greater than 200 base pairs (Figures 1 a-d) which are ideal for the identification of microorganisms. Alignment scores are represented by the red lines. The isolates were blasted on NCBI database and identified as: Lasiodiplodia theobromae, Fusarium proliferatum, Penicillium sp. and Aspergillus niger. Table 3 shows the taxonomic affinities of the isolates on Gen Bank using Basic Alignment Search Tool (BLAST) which relies on choosing the species with the highest similarity percentage based on nucleotide arrangement of the subject against the query sequences.

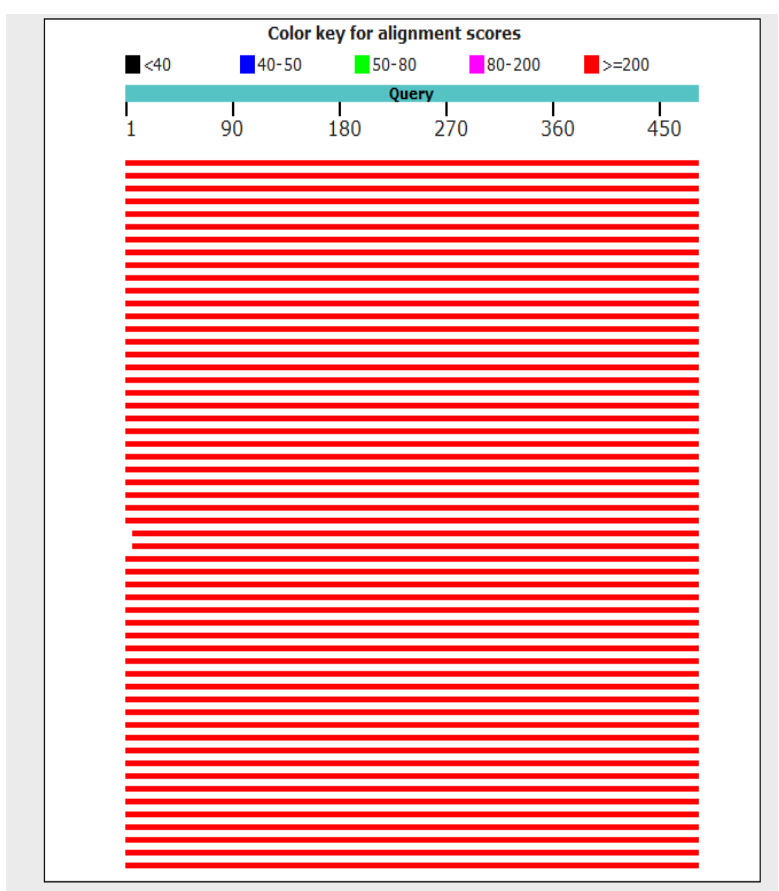

a

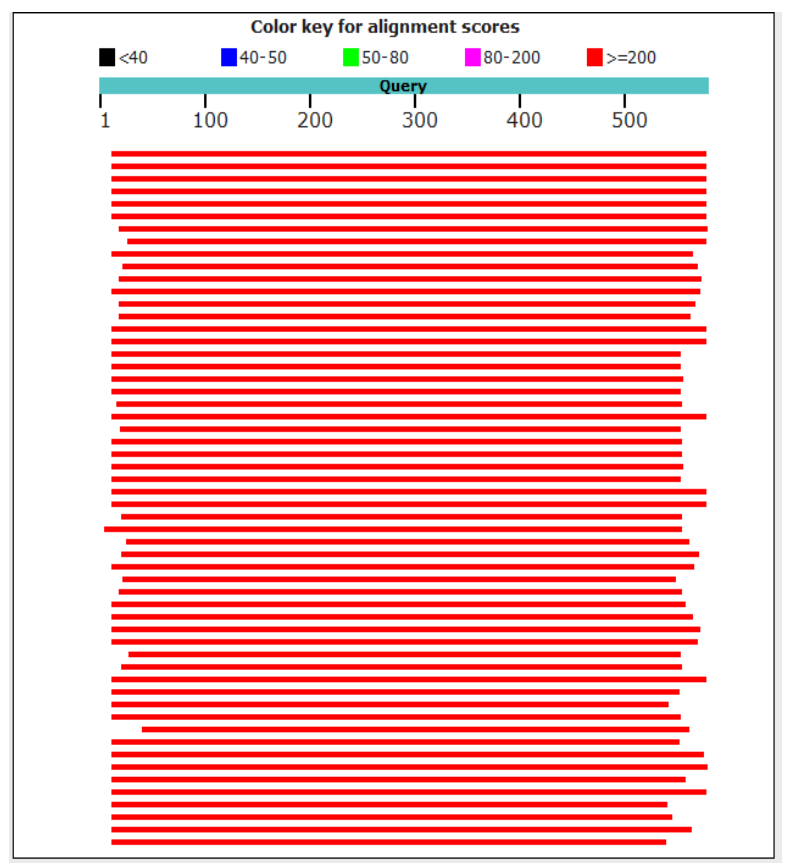

c

\section{Phylogenetic Analysis of Isolates}

The phylogenic tree is presented in Figure 2. Fusarium verticilioides, Physalospora zeicola, Penicillium mallochii, Penicillium sclerotiorum, Aspergillus aculeatinus and Aspergillus japonicus were most closely related to the fungal isolates obtained from Persea americana fruits. The vertical lines on the trees indicate how distantly or closely related the organisms are to each other. The greater the lengths of the vertical lines, the more the organisms differ evolutionarily.

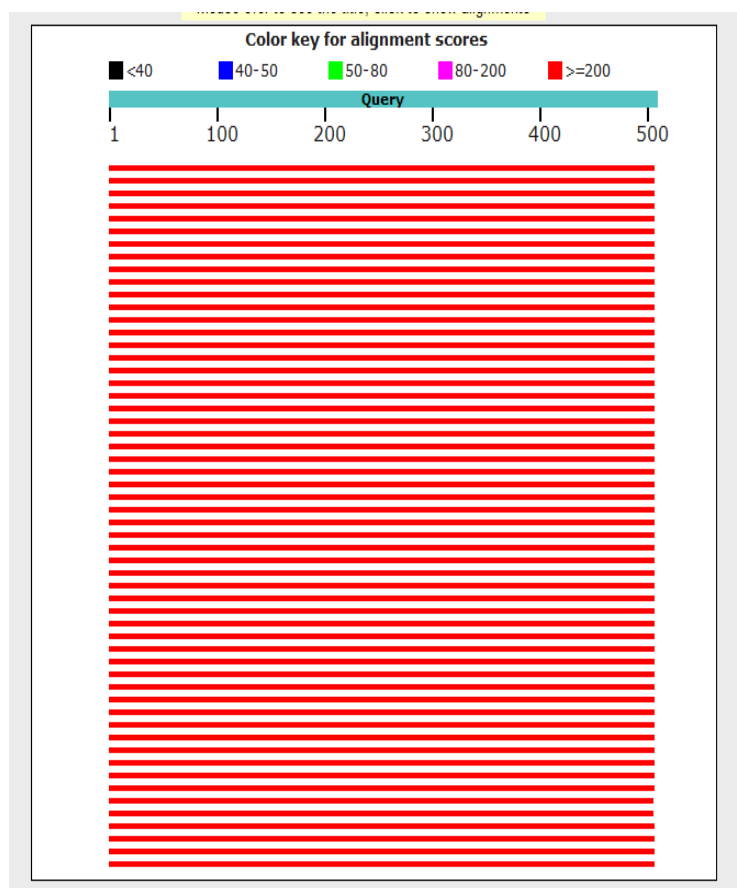

b

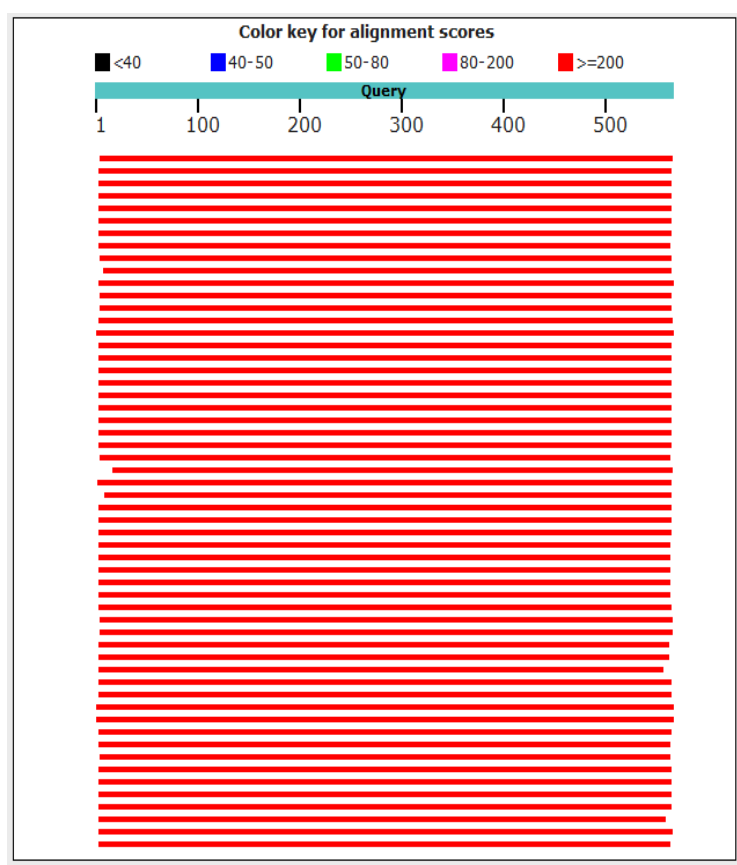

d

Figure 1: Sequence alignment of isolates 1,2, 3 and 4 represented by a, b, c and d, respectively 
Table 3: Putative taxonomic affinities of sequence types inferred from BLAST of ITS sequence

\begin{tabular}{llll}
\hline $\begin{array}{l}\text { Sample } \\
\text { ID }\end{array}$ & $\begin{array}{l}\text { Taxonomic } \\
\text { affinity }\end{array}$ & $\begin{array}{l}\text { GenBank } \\
\text { accession no. }\end{array}$ & $\begin{array}{l}\text { Percentage } \\
\text { similarity }\end{array}$ \\
\hline 1 & $\begin{array}{l}\text { Lasiodiplodia } \\
\text { theobromae }\end{array}$ & (MF495379.1) & 98.96 \\
2 & $\begin{array}{l}\text { Fusarium } \\
\text { proliferatum }\end{array}$ & (MH997878.1) & 95.06 \\
3 & $\begin{array}{l}\text { Penicillium } \\
\text { sp. }\end{array}$ & (KX961214.1) & 98.76 \\
4 & $\begin{array}{l}\text { Aspergillus } \\
\text { niger }\end{array}$ & (MN474007.1) & 98.22 \\
\hline
\end{tabular}

The sequences of the isolates were submitted on Gen Bank and accession numbers were assigned to each isolate. The accession numbers are in parenthesis.

Lasiodiplodia theobromae (MN626622) strain RCCBR_AEAPR1

Fusarium proliferatum

(MT682896) strain RCCBR_AEAPR2

Penicillium sp. (MT682897) Strain RCBBR_AEART1

Aspergillus niger (MT655951) Strain RCBBR_AEART2

\section{DISCUSSION}

The morphology of isolated fungi on PDA were cotton-like blackish grey spots, white villous colonies, greyish powdery spores and black spores for Lasiodiplodia theobromae, Fusarium proliferatum, Penicillium sp. and Aspergillus niger, respectively. Cultural method of identification of fungi may result in a species list that misinterprets the fungal community. Molecular techniques have proven to be more dependable than cultural method which applies only morphological and microscopic identification techniques. The molecular technique used in this study was polymerase chain reaction amplification of the ITS1-2 gene sequences of the fungal organisms isolated from Persea americana and subsequent sequencing of the PCR products. This method was able to identify four fungi associated with Persea americana fruit viz: Lasiodiplodia theobromae, Fusarium proliferatum, Penicillium sp. and Aspergillus niger.

Lasiodiplodia theobromae belongs to the phylum Ascomycota, class Dothideomycetes, order Botryosphaeriales and family Botryosphaeriaceae. Lasiodiplodia theobromae is both a plant and animal pathogen. Úrbez-Torres et al. (2008) observed dark-brown lesion and black wood streaking symptoms on grape vines in Mexico which led to dieback and canker on the infected plants. The causative organisms were culturally, morphologically and molecularly identified to be Lasiodiplodia theobromae and Diplodia seriata. Symptoms caused by $L$. theobroaeon various plants include black kernel rot, die back, bleached and stunted shoots in the spring, delay or lack of growth in the spur positions of the bud, bleached canes and bud necrosis (Rodríguez-Gálvez et al., 2014). L. theobromae was also found to be responsible for subcutaneous infection in humans (Papacostas et al., 2015).

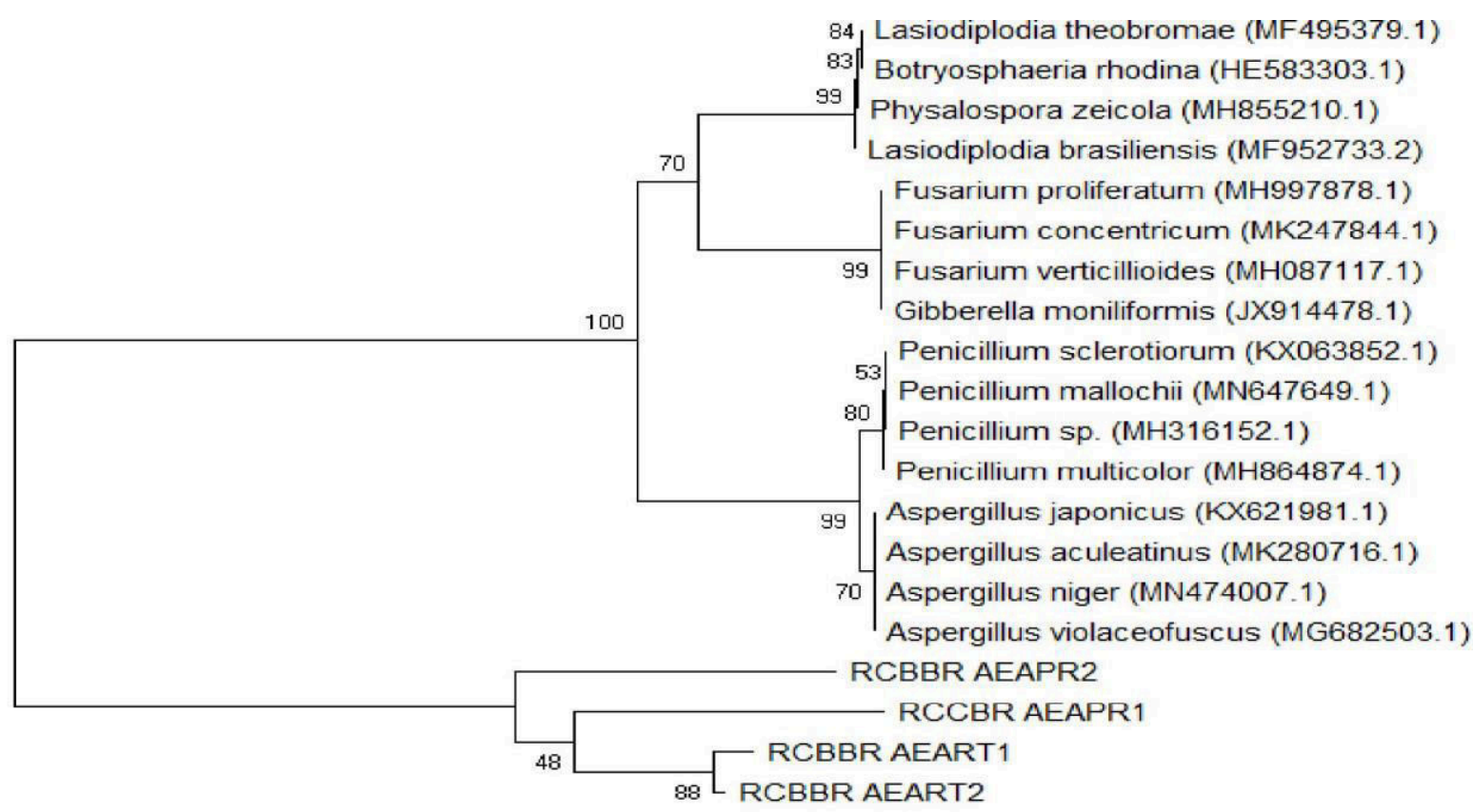

1

Figure 2: Neighbor-joining phylogenetic tree based on the sequenced ITS1-2 regions 
Fusaruim proliferatum causes root rot in pear (Chang et al., 2015) as well as black spot disease. It infects the fruits, leaves and shoot of trees of different varieties of pear, causing leaf fall, early fruit drop, fruit decay and post-harvest decay. Udoh et al. (2015) reported the occurrence of Fusarium moniliforme, Penicillium expansum, Mucor indiscus and Rhizopus nigrican on Persea americana fruit in Enugu State, Nigeria.

Penicillium and Aspergillus are members of the division Ascomycota, class Eurotiomycetes, order Eurotiales and family Trichocomaceae. The mycotoxin, patulin is produced by the genera Penicillium and Aspergillus. This mycotoxin is regarded as a potential antibiotic but with recent studies, it was discovered to be toxic to humans causing ulcer, vomiting, nausea and hemorrhage. Penicillium sp. are found in diverse habitats ranging from food products to vegetations, to soil, to indoor environments and in the air (Visagie et al., 2014). Some species are employed industrially for the production of enzymes (Terrasan et al., 2010), and antibiotics such as penicillin, fermented sausages and cheese (Ludemann et al., 2010; Giraud et al., 2010).

Aspergillus niger produces ochratoxin A, aflatoxins and fumonisin B2, (Al-Abdalall, 2009; Noonim et al., 2009). These mycotoxins can cause different diseases in humans (Truckesses and Scott, 2008). A. niger has been isolated from various plants and it is responsible for many rot diseases in plants (Guatam et al., 2011). Aspergillus niger is known to produce mycotoxins which cause diseases of the kidney and liver (Guatam et al., 2011). A. niger has been reported to cause necrotizing fungal pneumonia (Pearson et al., 2010) in man and when inhaled in sufficient quantity, it can lead to aspergillosis in humans.

Morphological and microscopic characteristics of the microorganisms are the basis of cultural techniques of microbial identification. This method can lead to misidentification of organisms and cannot be used to specifically identify microorganisms to the species level. The use of molecular techniques which is based on the genetic composition of organisms provides accurate identification of microorganisms as the genetic make-up of all living things differ at some level. Many scientists in developing countries of the world mostly dwell on the use of cultural techniques in the identification of microorganisms and this can lead to misinterpretation of the fungal community. The molecular techniques used in this study were successful in identifying the fungal isolates associated with avocado fruits. The ecology and economic importance of the fungal isolates have been highlighted in order to provide the information required for researchers to proffer measures towards enhancing fruit protection.

\section{CONCLUSION}

The techniques employed in this study led to the identification of the four (4) fungi isolated from Persea americana. The fungal isolates were identitified as Lasiodiplodia theobromae, Fusarium proliferatum, Penicillium sp. and Aspergillus niger. These fungi are pathogenic to different plants. Plant pathogens do not only cause deterioration and discoloration of plant produces but also lead to reduction in market value of food products. Accurate identification of microorganisms is essential for scientists in many areas of research and industry. Correct identification of plant pathogens will help farmers and scientists proffer the necessary and effective preventive/control measures in order to increase crop yield both in the field and also during storage. This study has promoted the knowledge of some of the fungal species associated with Persea americana fruits which will help researchers to proffer preventive/control measures against some of these organisms that might be pathogenic to avocado fruits in order to enhance fruit protection.

\section{REFERENCES}

Al-Abdalall A.H. (2009). Production of aflatoxins by Aspergillus flavus and Aspergillus niger strains isolated from seeds of pulses. Journal of Food Agriculture \& Environment, 7, 33-39

Belé M.P. (2010). El Aguacate y sus Diferentes Aplicaciones en 25 Recetas. Universidad de Cuencas, Ecuador, pp. 19-26

Bergh B.D. (2012). Nutritious value of avocado. California Avocado Society Yearbook, 76,123-135

Chang K., Hang S., Conner R., Ahmed H.U., Zhou Q., Turnbull G.D., Strelkov S.E., McLaven D.L. and Gossen B.D. (2015). First report of Fusarium proliferatum causing root rot in pear (Glycine max L.) in Canada. Crop Prot., 67, 52-58

Djeugap F.J., Tsompbeng G.N., Keuete K.E., Yaouba A. and Serferbe S. (2015). Isolation and identification of fungi associated with avocado fruits from local markets of the West Region of Cameroon. Int. J. Agric. Biosci., 4 (2), 64-68

Duarte P.F., Chaves M.A., Borges C.D. and Mendonça C.R. (2016). Avocado: Characteristics, health benefits and uses. Ciência Rural, Santa Maria, 46 (4), 747-754

Eze S.N. and Okeke E.C. (2012). Consumption patterns of iron and vitamin A rich foods and contributions of food Groups to nutrient intakes of pregnant women in Nsukka Local Government Area of Enugu State, Nigeria. Agro-Science, 11 (2), 9-16

Gautam A.K., Sharm S., Avasthi S. and Bhadauria R. (2011). Diversity, pathogenicity and toxicology of Aspergillus niger: an important spoilage fungi. Res. J. Microbio., 6, 270-280

Giraud F., Giraud T. and Aguileta G. (2010). Microsatellite loci to recognize species for the cheese starter and contaminating strains associated with cheese manufacturing. Int. J. Food Microbio., 137, 204-213 
Kebede M. and Belay A. (2019). Fungi associated with post-harvest avocado fruit rot at Jimma town, Southwestern Ethiopia. J. Plant Path. Microbio., 10 (2), 2157-7472

Kumar S., Stecher G., Li M., Knyaz C. and Tamura K. (2018). MEGA X: Molecular evolutionary genetics analysis across computing platforms. Molecular Biology \& Evolution, 35, 1547-1549

Long P.E., Williams K.H., Hubbard S.S. and Banfield J.F. (2016). Microbial metagenomics reveals climate-relevant subsurface biogeochemical processes. Trends in Microbio., 24 (8), 600-610

Ludemann V., Greco M. and Rodríguez M.P. (2010). Conidial production by Penicillium nalgiovense for use as starter cultures in dry fermented sausages by solid state fermentation. LWT-Food Sci. Tech., 43, 315-318

Machado M., Collazo C.M., Renaud M.A., et al. (2012). First report of Phytophthora palmivora butler causing root rot on avocado (Persea americana Mill.) in Cuba. Canadian J. Plant Path., 34 (2), 323-348

Machado M., Collazo C., Pena M., Coto O. and Lopez M.O. (2013). First Report of Phytophthora nicotianae in avocado trees (Persea americana) in Cuba. New Dis. Rep., 28 (9), 1

Noonim P., Mahakarnchanakul W., Nielsen K.F., Frisvad J.C. and Samson R.A. (2009). Fumonisin B2 production by Aspergillus niger in Thai coffee beans. Food Add. Contam. Part A, 26, 94-100

Papacostas L.J., Henderson A., Choong K. and Sowden D. (2015). An unusual skin lesion caused by Lasiodiplodia theobromae. Med. Myco. Case Rep., 8, 44-46

Person A.K., Chudgar S.M., Norton B.L., Tong B.C. and Stout J.E. (2010). Aspergillus niger: An unusual cause of invasive pulmonary aspergillosis. J. Med. Microbio., 59, 834-838

Radha T. and Mathew L. (2007). Fruit Crops (Horticulture Science Series). New India Publishing Agency: New Delhi, India, pp. 444

Rodríguez-Gálvez E., Maldonado A. and Alves E. (2014). Identification and Pathogenicity of Lasiodiplodia theobromae causing dieback of table grapes in Peru. Europ. J. Plant Path., 141 (3), 477-489

Schaffer B., Wolstenholme B.N. and Whiley A.W. (2013). The Avocado: Botany, Production and Uses ( $2^{\text {nd }}$ ed.), Center for Agriculture and Bioscience International (CABI), pp. 560
Schoch C.L., Keith A.S., Sabine H., et al. (2012). Nuclear ribosomal internal transcribe spacer (ITS) Region as a universal DNA barcode marker for fungi. Proceeding of the National Academy of Sciences of United States, 109 (16), 6241-6246

Tedersoo L., Anslan S., Bahram M., et al. (2015). Shotgun metagenomes and multiple primer pairbarcode combinations of amplicons reveal biases in metabarcoding analyses of fungi. MycoKeys, 10, 1-43

Terrasan C.R., Temer B. and Duarte M.C. (2010). Production of xylanolytic enzymes by Penicillium janczewskii. Biores. Tech., 101, 4139-4143

Truckesses M.W. and Scott P.M. (2008). Mycotoxins in botanicals and dried fruits: A review. Food Add. Contam., 25, 181-192

Udoh I.P., Eleazer C.L., Ogeneh B.O. and Ohanu M.E. (2015). Studies on fungi responsible for the spoilage/deterioration of some edible fruits and vegetables. Adv. Microbio., 5 (4), 285-290

Úrbez-Torres J.R., Leavit G.M., Guerrero J.C., Guevara J. and Gubler W.D. (2008). Identification and pathogenicity of Lasiodiplodia theobromae and Diplodia seriata, the causal agents of bot canker disease of grapevines in Mexico. Plant Dis., 92 (4), 519-529

Visagie M.J., Houbraken J., Frisvad J.C., et al. (2014). Identification and nomenclature of the genus Penicillium. Studies Myco., 78, 343-371

Wang M., Zheng Y., Khuong T., Carol J. and Lovatt C.J. (2012). Effect of harvest date on the nutritional quality and antioxidant capacity in 'Hass' avocado during storage. Food Chem., 135 (2), 694-698

Wanjiku E.K., Waceke J.W., Wanjala B.W. and Mbaka J.N. (2020). Identification and pathogenicity of fungal pathogens associated with stem end rots of avocado fruits in Kenya. International Journal of Microbiology, Volume 2020, Article ID 4063697. Available at https://doi.org/10.1155/2020/4063697

Xue K., Yuan M.M., Shi Z.J., et al. (2016). Tundra soil carbon is vulnerable to rapid microbial decomposition under climate warming. Nat. Clim. Change, 6 (6), 595-600

Yahia E.M. and Woolf A.B. (2011). Postharvest Biology and Technology of Tropical and SubTropical Fruits. Woodhead Publishing Series in Food Science, Technology and Nutrition, pp. 560 